\title{
KOMPETENSI KEPRIBADIAN GURU BK \\ (Survei pada Guru Bimbingan dan Konseling Sekolah Menengah \\ Pertama dan Sederajat Se-Kecamatan Citeureup)
}

\author{
Dewi Sapto Rini ${ }^{1}$ \\ Dewi Justitia ${ }^{2}$ \\ Dharma Setiawaty R. ${ }^{3}$
}

\begin{abstract}
Abstrak
Penelitian ini bertujuan untuk mengetahui gambaran empirik mengenai kompetensi kepribadian guru bimbingan dan konseling di SMP/ sederajat se-Kecamatan Citeureup. Metode yang digunakan adalah metode deskriptif, dengan jenis survei. Populasi penelitian ini adalah guru BK di SMP/ sederajat se-Kecamatan Citeureup. Teknik pengambilan sampel yang digunakan adalah sampling jenuh dengan jumlah sampel sebanyak 34 responden. Pengumpulan data menggunakan instrumen kompetensi kepribadian guru BK. Pengujian instrumen diolah menggunakan Microsoft Excel. Uji validitas dari 34 butir pernyataan didapatkan 29 butir pernyataan valid dan 5 butir pernyataan drop. Uji reliabilitas menunjukan angka sebesar 0,99 yang berarti kehandalan instrumen sangat tinggi. Hasil penelitian menunjukan bahwa guru BK di SMP/sederajat se-Kecamatan Citeureup yang berada pada kategori kompeten sebanyak 26 guru BK $(76,5 \%)$, sedangkan yang berada pada kategori tidak kompeten sebanyak 8 orang $(23,5 \%)$. Berdasarkan hasil tersebut dapat diketahui bahwa kompetensi kepribadian guru BK di SMP/sederajat se-Kecamatan Citeureup pada umumnya berada pada kategori kompeten yang berarti guru BK sudah mampu menampilkan kepribadian yang baik sebagai guru BK di sekolah. Meskipun begitu, masih perlu adanya pengembangan terutama terhadap guru BK yang tidak kompeten. Rekomendasi ditujukan kepada guru BK agar terus belajar dan senantiasa meningkatan kompetensi kepribadiannya.
\end{abstract}

Kata Kunci: Kompetensi, kepribadian, guru bimbingan dan konseling.

\section{PENDAHULUAN}

Keberadaan bimbingan dan konseling di sekolah bertujuan untuk membantu siswa mengembangkan dirinya dan menyelesaikan masalahnya sehingga tahap perkembangannya tidak terganggu. Untuk mencapai tujuan ini, maka perlu dilaksanakan layanan bimbingan dan konseling yang bermutu. Perwujudan dari layanan bimbingan dan konseling yang bermutu di sekolah tidak lepas dari peran guru bimbingan dan konseling (selanjutnya disingkat BK). Keberhasilan layanan bimbingan dan konseling sangat dipengaruhi oleh kinerja guru BK dalam melaksanakan tugasnya. Guru BK di sekolah memiliki peran dan tugas yang berbeda dengan guru mata pelajaran. Selain memiliki tugas untuk membimbing semua siswa asuhnya, guru BK memiliki tugas untuk memberikan layanan konseling kepada siswa yang memerlukan.

$$
\text { Beragamnya tugas yang }
$$
ditanggungnya, guru BK harus menguasai berbagai kompetensi untuk menunjang kinerjanya. Profesi guru BK yang termasuk dalam profesi pendidikan, sudah pasti memiliki standar kualifikasi dan kompetensi

\footnotetext{
${ }^{1}$ Mahasiswa Program Studi Bimbingan dan Konseling FIP UNJ, dewi.saptorini@gmail.com

${ }^{2}$ Dosen Program Studi Bimbingan dan Konseling FIP UNJ, justitiadewi@yahoo.com

${ }^{3}$ Dosen Program Studi Bimbingan dan Konseling FIP UNJ, dharmasetiawaty@gmail.com
} 
yang dijadikan sebagai acuan atau pedoman guru BK dalam menjalankan tugas dan peranannya di sekolah. Hal ini ditegaskan dalam Permendiknas Nomor 27 tahun 2008 tentang Standar Kualifikasi Akademik dan Kompetensi Konselor. Di dalamnya dirumuskan empat kompetensi yang harus dimiliki guru BK sebagai konselor sekolah, yakni kompetensi pedagogik, kompetensi kepribadian, kompetensi sosial dan kompetensi profesional.

Sebagaimana yang telah disebutkan bahwa salah satu kompetensi yang harus dimiliki guru BK adalah kompetensi kepribadian. Pasalnya untuk mewujudkan pelayanan yang optimal dan bermutu, layanan bimbingan dan konseling harus diberikan oleh guru BK yang profesional dan memiliki kepribadian menyenangkan. Seperti yang tercantum dalam Permendiknas Nomor 27 tahun 2008 bahwa unjuk kerja guru BK/ konselor harus dilandasi oleh sikap, nilai, dan kecendrungan pribadi yang mendukung. Oleh karena itu, kompetensi kepribadian seorang guru BK merupakan faktor yang sangat penting dan berpengaruh terhadap kebermutuan layanan bimbingan dan konseling di sekolah.

Berdasarkan hasil studi pendahuluan yang dilakukan dengan menyebarkan angket mengenai "persepsi siswa terhadap guru BK di sekolah" kepada beberapa siswa SMP di kecamatan Citeureup. Hasilnya masih banyak siswa yang menganggap guru BK sebagai polisi sekolah karena guru BK sering melakukan razia dan menghukum siswa yang melakukan pelanggaran tata tertib. Guru BK pernah terlihat sedang mencubit, menjewer dan memukul siswa yang bermasalah (ketahuan merokok, terlibat tawuran dan berpakaian tidak sesuai aturan). Guru BK kurang senyum dan cenderung cuek saat berpapasan dengan siswa. Guru BK kurang memberikan perhatian dan peka kepada siswa yang memiliki masalah akademik dan ekonomi di sekolah. Guru BK masih jarang melayani siswa yang ingin konseling, bahkan ada guru BK yang menolak untuk memberikan konseling karena kesibukan lainnya. Guru
BK telat masuk ke dalam kelas atau bahkan sengaja tidak masuk ke dalam kelas. Ketika masuk kelas masih ada guru BK yang hanya duduk diam memberikan materi, tanpa menggunakan media apapun. Kemudian sebagian siswa juga mengungkapkan bahwa hubungannya dengan guru BK masih belum akrab dan merasa canggung untuk meminta konseling dengan guru BK.

Berdasarkan permasalahan yang telah dikemukakan, rumusan masalah dalam penelitian adalah "Bagaimana kompetensi kepribadian guru BK di SMP dan sederajat se-Kecamatan Citeureup?"

\section{KAJIAN TEORITIK KOMPETENSI}

Sagala menjelaskan bahwa
kompetensi adalah perpaduan dari penguasaan, pengetahuan, keterampilan, nilai dan sikap yang direfleksikan dalam kebiasaan berpikir dan bertindak dalam melaksanakan tugas/pekerjaannya (Sagala, 2011). Michael Zwell dalam Wibowo mengungkapkan bahwa terdapat beberapa faktor yang dapat mempengaruhi kecakapan kompetensi seseorang, yaitu: 1) keyakinan dan nilainilai, 2) keterampilan, 3) pengalaman, 4) kepribadian, 5) motivasi, 6) isu emosional, 7) kemampuan intelektual (pendidikan), serta 8) budaya organisasi (Wibowo, 2007).

\section{KEPRIBADIAN}

Moh. Roqib mengartikan kepribadian merupakan organisasi faktorfaktor biologis, psikologis, sosiologis yang mendasari perilaku individu. Kepribadian mencakup kebiasaan-kebiasaan, sikap yang dimilliki seseorang yang berkembang apabila orang tadi berhubungan dengan orang lain (Roqib, 2009). Kepribadian erat kaitannya dengan tingkah laku, karena segala tingkah laku individu merupakan manivestasi dari kepribadian yang dimilikinya.

\section{GURU BIMBINGAN DAN KONSELING \\ Guru bimbingan dan konseling}


atau konselor adalah guru yang mempunyai tugas, tanggung jawab, wewenang, dan hak secara penuh dalam kegiatan bimbingan dan konseling terhadap sejumlah peserta didik. Selanjutnya Dewa Ketut Sukardi dalam bukunya mengatakan bahwa guru bimbingan konseling adalah seorang guru yang bertugas memberikan bantuan psikologis dan kemanusiaan secara ilmiah dan profesional sehingga seorang guru bimbingan konseling harus berusaha menciptakan komunikasi yang baik dengan murid dalam menghadapi masalah dan tantangan hidup (Sukardi, 2008).

\section{KOMPETENSI KEPRIBADIAN GURU BK}

Kompetensi kepribadian adalah salah satu kompetensi yang harus dimiliki oleh seorang guru yang berkaitan dengan tingkah laku pribadi guru itu sendiri yang kelak harus memiliki nilai-nilai luhur sehingga terlihat dalam perilaku sehari-hari (Saudagar, 2011). Kompetensi kepribadian yang harus dikuasai dan ditampilkan oleh guru BK di sekolah tercantum dalam Pemendiknas Nomor 27 Tahun 2008 yang dipetakan menjadi beberapa aspek sebagai berikut:

1. Beriman dan bertaqwa kepada Tuhan Yang Maha Esa

Kompetensi kepribadian beriman dan bertaqwa kepada Tuhan Yang Maha Esa, yang harus dimiliki guru BK yaitu: 1) menampilkan kepribadian yang beriman dan bertaqwa kepada Tuhan Yang Maha Esa, 2) Konsisten dalam menajalankan kehidupan beragama dan toleran terhadap pemeluk agama lain, dan 3) berakhlak mulia dan berbudi pekerti luhur.

2. Menghargai dan menjunjung tinggi nilainilai kemanusiaan, individualitas, dan kebebasan memilih

Kompetensi kepribadian menghargai dan menjunjung tinggi nilai-nilai kemanusiaan, individualitas, dan kebebasan memilih, yang harus dimiliki guru BK yaitu: 1) mengaplikasikan pandangan positif dan dinamis tentang manusia sebagai makhluk spiritual, bermoral, sosial, individual, dan berpotensi, 2) menghargai dan mengembangkan potensi positif individu pada umumnya dan konseli pada khususnya, 3) peduli terhadap kemaslahatan manusia pada umumnya dan konseli pada khususnya, 4) menjunjung tinggi harkat dan martabat manusia sesuai dengan hak asasinya, 5) toleran terhadap permasalahan konseli, serta 6) bersikap demokratis.

3. Menunjukan integritas dan stabilitas kepribadian yang kuat

Kompetensi kepribadian menunjukan integritas dan stabilitas kepribadian yang kuat, yang harus dimiliki guru BK yaitu: 1) menampilkan kepribadian dan perliaku yang terpuji (seperti berwibawa, jujur, sabar, ramah, dan konsisten), 2) menampilkan emosi yang stabil, 3) peka, bersikap empati, dan menghormati keragaman dan perubahan, serta 4) toleransi tinggi terhadap konseli yang menghadapi stres dan frustasi.

4. Menampilkan kinerja yang berkualitas tinggi

Kompetensi kepribadian menampilkan kinerja yang berkualitas tinggi, yang harus dimiliki guru BK yaitu: 1) menampilkan tindakan yang cerdas, kreatif, inovatif, dan produktif, 2) bersemangat, berdisiplin, dan mandiri, 3) berpenampilan menarik dan menyenangkan, serta 4) berkomunikasi secara efektif.

\section{METODOLOGI PENELITIAN}

Penelitian ini dilakukan di Sekolah Menengah Pertama yang berada di Kecamatan Citeureup yang jumlahnya sebanyak 30 sekolah. Waktu penelitian dilaksanakan dari bulan Januari sampai dengan Desember 2015. Penelitian ini menggunakan pendekatan kuantitatif dengan metode penelitian deskriptif. Jenis yang digunakan dalam penelitian deskriptif ini adalah survei. Menurut Sugiyono, metode survei digunakan untuk mendapatkan data dari tempat tertentu yang alamiah (bukan 
buatan), tetapi peneliti melakukan perlakuan dalam pengumpulan data, misalnya dengan mengedarkan kuesioner, test, wawancara terstruktur dan sebagainya (Sugiyono, 2011).

Dalam penelitian ini yang menjadi populasipenelitian adalah Guru BK di Sekolah Menengah Pertama/ sederajat se-Kecamatan Citeureup yang jumlahnya sebanyak 34 orang. Teknik pengambilan sampel yang digunakan dalam penelitian ini adalah pengambilan sampel menggunakan sampling jenuh. Sugiyono menjelaskan sampling jenuh adalah teknik penentuan sampel bila semua anggota populasi digunakan sebagai sampel.

Dalam penelitian ini, pengumpulan data dilakukan melalui angket. Sugiyono menjelaskan angket (kuesioner) merupakan teknik pengumpulan data yang dilakukan dengan cara memberi seperangkat pertanyaan atau pernyataan tertulis kepada responden untuk dijawabnya. Uji validitas dan reliabilitas dilakukan menggunakan aplikasi Ms. Excel 2007. Uji validitas dari 34 butir pernyataan didapatkan 29 butir pernyataan valid dan 5 butir pernyataan drop. Uji reliabilitas menunjukan angka sebesar 0,99 yang berarti kehandalan instrumen sangat tinggi.

Penyajian data dari hasil penelitian ini akan dikategorisasikan dalam dua kategorisasi, yaitu kompeten dan tidak kompeten. Cara pengkategorisasian data pada penelitian ini menggunakan pendekatan Penilaian Acuan Kriteria (PAK) atau disebut juga Penilaian Acuan Patokan (PAP). Pendekatan ini merupakan model pendekatan penilaian yang mengacu pada suatu kriteria pencapaian yang telah ditetapkan sebelumnya. Kriteria atau patokan yang digunakan dalam PAK/PAP ini bersifat mutlak, artinya kriteria ini bersifat tetap setidaknya untuk jangka waktu tertentu dan berlaku bagi responden yang terkait. Dalam penelitian ini, peneliti membuat kategorisasi dengan kriteria kompeten jika skor total $>75 \%$ dan tidak kompeten jika skor total $<75 \%$.

\section{HASIL DAN PEMBAHASAN}

Berdasarkan pengolahan data yang telah dilakukan, maka hasil penelitian ini dapat digambarkan sebagai berikut:

Tabel 1

Gambaran Kompetensi Kepribadian Guru BK

SMP di Kecamatan Citeureup

\begin{tabular}{cccc}
\hline $\begin{array}{c}\text { Persen- } \\
\text { tase Skor }\end{array}$ & Kategori & Frekuensi & $\%$ \\
\hline$\geq 75 \%$ & Kompeten & 26 & $76,5 \%$ \\
$<75 \%$ & Tidak Kompeten & 8 & $23,5 \%$ \\
& Total & $\mathbf{3 4}$ & $\mathbf{1 0 0 \%}$ \\
\hline
\end{tabular}

Tabel di atas menggambarkan bahwa sebanyak 26 orang dari 34 orang guru BK atau sebanyak $76,5 \%$ termasuk dalam kategori kompeten yang artinya 26 orang guru BK ini sudah mampu menampilkan kepribadian yang sesuai sebagai guru BK yang ideal di sekolah. Guru BK mampu menjadi teladan bagi siswanya dalam menampilkan kepribadian yang beriman dan bertaqwa kepada Tuhan Yang Maha Esa, guru BK mampu menghargai dan menjunjung tinggi nilai-nilai kemanusiaan, indvidualitas, dan memberikan kebebasan memilih kepada siswa sehingga siswa merasa berharga, guru BK mampu menunjukan integritas dan stabilitas kepribadian yang kuat, dan mampu menampilkan kinerja berkualitas tinggi sebagai seorang konselor sekolah. Selanjutnya 8 orang guru BK lainnya masih termasuk dalam kategori tidak kompeten yang artinya bahwa 8 orang guru tersebut belum mampu menguasai beberapa indikator kompetensi kepribadian yang sesuai sebagai guru BK yang ideal di sekolah.

Berikut ini disajikan pula tabel yang menggambarkan hasil penelitian mengenai kompetensi kepribadian guru BK SMP di Kecamatan Citeureup berdasarkan satuan pendidikan, jenis kelamin, usia, masa kerja dan juga latar belakang pendidikan guru.

Tabel 2

Gambaran Kompetensi Kepribadian Guru BK 


\begin{tabular}{|c|c|c|c|}
\hline \multirow[b]{2}{*}{ Kelompok } & \multicolumn{2}{|c|}{ Kategori } & \multirow{2}{*}{$\begin{array}{l}\text { Skor } \\
\text { Rerata }\end{array}$} \\
\hline & Kompeten & $\begin{array}{c}\text { Tidak } \\
\text { Kompeten }\end{array}$ & \\
\hline $\begin{array}{l}\text { SMP Negeri } \\
\text { (5 orang) }\end{array}$ & $100 \%$ & $0 \%$ & 102,6 \\
\hline $\begin{array}{l}\text { SMP Swasta } \\
\text { (17 orang) }\end{array}$ & $70,6 \%$ & $29,4 \%$ & 90,88 \\
\hline $\begin{array}{c}\text { MTs } \\
\text { (12 orang) }\end{array}$ & $75 \%$ & $25 \%$ & 91,83 \\
\hline $\begin{array}{l}\text { Laki-laki } \\
\text { (18 orang) }\end{array}$ & $72,2 \%$ & $27,8 \%$ & 91,61 \\
\hline $\begin{array}{l}\text { Perempuan } \\
\text { (16 orang) }\end{array}$ & $81,3 \%$ & $18,7 \%$ & 94,43 \\
\hline $\begin{array}{c}\text { Usia } 26-35 \\
\text { Tahun } \\
\text { (9 orang) }\end{array}$ & $77,8 \%$ & $22,2 \%$ & 91,89 \\
\hline $\begin{array}{c}\text { Usia } 36-45 \\
\text { Tahun } \\
\text { (16 orang) }\end{array}$ & $68,75 \%$ & $31,25 \%$ & 90,56 \\
\hline $\begin{array}{c}\text { Usia } 46-55 \\
\text { Tahun } \\
\text { (9 orang) }\end{array}$ & $88,9 \%$ & $11,1 \%$ & 98,22 \\
\hline $\begin{array}{c}\text { Masa Kerja } 1- \\
15 \text { Tahun } \\
\text { (26 orang) }\end{array}$ & $69,2 \%$ & $30,8 \%$ & 90,85 \\
\hline $\begin{array}{c}\text { Masa Kerja } 16- \\
30 \text { Tahun } \\
\text { (8 orang) }\end{array}$ & $100 \%$ & $0 \%$ & 99,75 \\
\hline
\end{tabular}

\begin{tabular}{cccc}
\hline & \multicolumn{2}{c}{ Kategori } & Skor \\
Kelompok & Kompeten & $\begin{array}{c}\text { Tidak } \\
\text { Kompeten }\end{array}$ & Rerata \\
\hline $\begin{array}{c}\text { S1 BK } \\
\text { (6 orang) }\end{array}$ & $100 \%$ & $0 \%$ & 102,5 \\
S1 NON BK & $71,4 \%$ & $28,6 \%$ & 90,89 \\
(28 orang) & & & \\
\hline
\end{tabular}

Tabel di atas menggambarkan perbedaan kompetensi guru BK berdasarkan jenis satuan pendidikan, jenis kelamin, usia, masa kerja, dan latar belakang pendidikan guru BK tresebut. Dari tabel tersebut dapat dilihat bahwa kompetensi kepribadian guru BK berdasarkan kelompok satuan pendidikan, kompetensi kepribadian guru BK di SMP Negeri memiliki skor rerata tertinggi dibandingkan dengan guru BK di SMP swasta dan MTs. Data ini dapat diartikan bahwa penguasaan kompetensi kepribadian guru BK di SMP Negeri se-Kecamatan Citeureup sangat baik atau lebih baik daripada guru BK di SMP swasta dan MTs di Kecamatan Citeureup.

Tabel di atas juga menggambarkan kompetensi kepribadian guru BK berdasarkan kelompok jenis kelamin, hasilnya menunjukan bahwa guru BK perempuan memiliki skor rerata kompetensi yang lebih tinggi dibanding skor rerata guru BK lakilaki. Hal ini berarti guru BK perempuan mampu menampilkan kepribadian yang lebih baik. Seperti yang diungkapkan Hasanudin, dkk, bahwa perempuan melakukan hubungan sosial dengan lain secara lebih akrab dibanding yang dilakukan oleh laki-laki. Mereka membuka diri lebih banyak dan memberikan dukungan sosial, terutama dukungan emosional lebih banyak pada orang lain. Diakui bahwa perempuan lebih "ahli" menggunakan aspek emosi berupa touch, hear, smell and taste, dibanding laki-laki. Perempuan lebih hangat bahasa tubuhnya, tersenyum lebih banyak dibanding laki-laki, lebih memperhatikan pendengarnya ketika berbicara, mendekati orang lain lebih dekat, dan "melakukan sentuhan" pada orang lain lebih hangat (Hasanudin, 2011).

Jika dilihat berdasarkan kelompok usia, skor rerata paling tinggi diperoleh oleh guru BK dengan rentang usia 46-55 tahun dengan skor 98,22. Hal ini menunjukan bahwa guru BK usia tua memiliki kompetensi kepribadian yang lebih baik. Keadaan ini menunjukan guru BK usia 46-55 tahun yang ada di SMP kecamatan Citeureup selalu meng-upgrade dirinya sehingga mampu mengaplikasikan kompetensi kepribadian sesuai dengan pedoman yang berlaku.

Selanjutnya jika dilihat berdasarkan kelompok masa kerja, guru BK dengan masa kerja 16-30 tahun memiliki skor rerata yang lebih tinggi dibanding guru BK dengan masa kerja 1-15 tahun. Hal ini menunjukan bahwa guru BK dengan masa kerja lebih lama memiliki kompetensi kepribadian yang lebih baik. Keadaan ini dipengaruhi oleh jumlah pengalaman yang diterimanya, guru BK dengan masa kerja lebih lama akan lebih banyak pula mendapatkan pengalamannya 
yang tentu akan mempengaruhi tingkat kompetensinya karena memungkinkan mereka mendapatkan pengetahuan dan wawasan dari sosialisasinya dengan sesama rekan sejawat dan berbagai pelatihan yang diikutinya.

Kemudian jika dilihat berdasarkan kelompok latar belakang pendidikan, guru BK berlatar pendidikan S1 BK memperoleh skor rerata yang lebih tinggi dibanding skor rerata guru BK dengan latar belakang pendidikan S1 Non BK. Dapat dilihat adanya perbedaan yang cukup jauh antara skor rerata diantara keduanya. Sehingga dapat dikatakan bahwa latar belakang pendidikan sangat mempengaruhi kompetensi kepribadian guru BK SMP di Kecamatan Citeureup. Latar belakang pendidikan yang sesuai bidangnya akan membawa guru tersebut bekerja dengan kompetensi yang memadai.

Kompetensi kepribadian guru BK terdiri dari 4 aspek, yaitu aspek beriman dan bertaqwa kepada Tuhan Yang Maha Esa, aspek menghargai dan menjunjung tinggi nilai-nilai kemanusiaan, individualitas, dan kebebasan memilih, aspek menunjukan integritas dan stabilitas kepribadian yang kuat, dan aspek menampilkan kinerja berkualitas tinggi. Berikut ini disajikan pula tabel yang menggambarkan hasil penelitian mengenai kompetensi kepribadian guru BK SMP di Kecamatan Citeureup setiap aspeknya.

Tabel 3

Gambaran Kompetensi Kepribadian Per-Aspek

\begin{tabular}{|c|c|c|c|}
\hline \multirow[b]{2}{*}{ Aspek } & \multicolumn{2}{|c|}{ Kategori } & \multirow[b]{2}{*}{$\begin{array}{c}\% \\
\text { Aspek }\end{array}$} \\
\hline & Kompeten & $\begin{array}{c}\text { Tidak } \\
\text { Kompeten }\end{array}$ & \\
\hline $\begin{array}{l}\text { Beriman dan bertaqwa } \\
\text { kepada Tuhan Yang } \\
\text { Maha Esa }\end{array}$ & $100 \%$ & $0 \%$ & $92,21 \%$ \\
\hline $\begin{array}{l}\text { Mengharagi dan men- } \\
\text { junjung tinggi nilai- } \\
\text { nilai kemanusiaan, } \\
\text { individualitas, dan } \\
\text { kebebasan memilih }\end{array}$ & $88,2 \%$ & $11,8 \%$ & $81,75 \%$ \\
\hline $\begin{array}{l}\text { Menunjukan integritas } \\
\text { dan stabilitas kepriba- } \\
\text { dian yang kuat }\end{array}$ & $35,3 \%$ & $64,7 \%$ & $73,65 \%$ \\
\hline $\begin{array}{l}\text { Menampilkan kinerja } \\
\text { berkualitas tinggi }\end{array}$ & $61,8 \%$ & $38,2 \%$ & $75,63 \%$ \\
\hline
\end{tabular}

Berdasarkan tabel di atas dapat dilihat bahwa aspek kompetensi kepribadian yang paling dikuasai oleh guru BK SMP di Kecamatan Citeureup adalah aspek beriman dan bertaqwa kepada Tuhan Yang Maha Esa, sedangkan aspek yang paling rendah skornya adalah aspek menunjukan integritas dan stabilitas kepribadian yang kuat.

Aspek pertama dalam kompetensi keperibadian guru BK adalah beriman dan bertaqwa kepada Tuhan Yang Maha Esa yang dalam penelitian ini merupakan aspek yang paling dikuasai oleh guru BK SMP di Kecamatan Citeureup. Pada aspek ini 100\% dari 34 orang guru BK berada pada kategori kompeten, yang artinya semua guru BK sudah mampu menampilkan pribadi yang beriman dan bertaqwa kepada Tuhan Yang Maha Esa. Guru BK mampu menghormati semua warga sekolah tanpa terkecuali, rajin bersedekah, mampu menampilkan toleransi dalam beragama, konsisten dan disiplin dalam menjalankan ibadah. Hasil 100\% yang diperoleh dipengaruhi juga oleh keterbatasan angket yang digunakan dalam penelitian ini, sehingga ada kemungkinan pernyataan yang ada dalam angket belum cukup mewakili setiap indikator secara mendetail.

Aspek kedua adalah aspek menghargai dan menjunjung tinggi nilai-nilai kemanusiaan, individualitas, dan kebebasan memilih. Pada aspek ini $88,2 \%$ dari 34 orang guru BK berada pada kategori kompeten yang berarti bahwa sebagian besar guru BK sudah mampu menghargai dan menjunjung tinggi nilai-nilai kemanusiaan, individualitas, dan kebebasan memilih. Hal ini ditunjukan dengan sikap guru BK yang mampu memberikan penguatan positif kepada konseli yang berhasil mencapai tujuan konseling dan juga kepada siswa yang mampu menunjukan kemajuan, memberikan pujian kepada siswa yang berpastisipasi aktif dalam kelas dan kepada siswa yang sudah tidak melanggar perarturan lagi. Selain itu, guru BK mampu bersikap demokratis dengan memberikan kesempatan kepada siswa untuk memilih.

Aspek ketiga dalam kompetensi kepribadian adalah aspek menunjukan 
integritas dan stabilitas kepribadian yang kuat yang dalam penelitian ini mendapatkan skor persetase paling rendah. Pada aspek ini $64,7 \%$ dari 34 guru BK berada pada kategori tidak kompeten yang berarti bahwa sebagian guru BK SMP di Kecamatan Citeureup belum cukup mampu untuk menampilkan integritas dan stabilitas kepribadian yang kuat. Hasil penelitian menunjukan bahwa sebagian besar guru BK SMP di Kecamatan Citeureup belum mampu bersikap sabar, ramah (kurang menampilkan senyum, sapa, salam kepada siswa), emosi guru BK masih tidak stabil karena masih sering memarahi siswa, kurang peka dan empati terhadap masalah siswa, kurang mampu bersikap toleransi terhadap konseli yang sedang bermasalah atau frustasi.

Aspek keempat dan yang terakhir adalah aspek menampilkan kinerja yang berkualitas tinggi. Pada aspek ini $61,8 \%$ dari 34 guru BK berada pada kategori kompeten yang berarti bahwa sebagian besar guru BK di SMP kecamatan Citeureup sudah mampu menampilkan kinerja yang berkualitas tinggi. Hal ini dapat dilihat dari hasil penelitian yang mengungkapkan bahwa guru BK mampu berpenampilan menarik dan menyenangkan dengan memperhatikan kebersihan dan kerapihan pakaian yang digunakan setiap harinya. Hal ini merupakan modal awal guru BK untuk menarik perhatian siswa karena yang pertama terlihat adalah penampilan luar guru BK itu sendiri. Namun, hasil penelitian masih menunjukan bahwa masih terdapat guru BK yang kurang bersemangat dan disiplin. Hal ini dilihat dari masih adanya guru BK yang sengaja mengulur waktu untuk masuk kelas.

Kompetensi kepribadian yang baik pada guru tidak hanya ditampilkan di dalam kelas atau di ruangan konseling saja tapi juga harus di tampilkan selama berada di lingkungan sekolah bahkan dikehidupan bermasyarakat. Kompetensi kerpibadian seorang guru BK telah disebutkan dalam Peraturan Menteri Pendidikan Nasional No.27 Tahun 2008 Tentang Standar Kualifikasi Akademik dan Kompetensi Konselor. Hendaknya guru BK menguasai semua indikator maupun deskriptor yang tercantum didalamnya untuk mewujudkan layanan bimbingan dan konseling yang bermutu di sekolah.

\section{KESIMPULAN}

Berdasarkan hasil penelitian kompetensi kepribadian guru BK di SMP seKecamatan Citeureup yang telah dipaparkan sebelumnya, maka dapat disimpulkan sebagai berikut:

1. Kompetensi kepribadian guru BK di SMP se-Kecamatan Citeureup berada pada kategori kompeten sebanyak 26 orang $(76,5 \%)$, yang berarti bahwa sebagian guru BK sudah mampu menampilkan kepribadian yang ideal sebagai guru BK di sekolah.

2. Kompetensi kepribadian dalam aspek beriman dan bertaqwa kepada Tuhan Yang Maha Esa merupakan aspek yang paling dikuasai, dengan skor persentase sebesar 92,21\%, sedangkan aspek yang mendapat skor paling rendah atau kurang dikuasai oleh guru BK di SMP se-Kecamatan Citeureup adalah aspek menunjukan integritas dan stabilitas kepribadian yang kuat dengan skor persentase sebesar $73,85 \%$.

3. Secara rerata keseluruhan, guru BK di SMP Negeri memiliki kompetensi kepribadian yang lebih baik dibanding dengan guru BK di SMP swasta maupun MTs.

4. Secara rata-rata keseluruhan, guru BK perempuan memiliki kompetensi kepribadian yang lebih baik dibanding dengan guru BK laki-laki.

5. Guru BK berlatar belakang pendidikan S1 BK memiliki kompetensi yang lebih baik dibanding dengan guru BK berlatar belakang pendidikan S1 Non BK.

\section{SARAN}

Saran yang dapat diberikan berdasarkan hasil penelitian ini adalah sebagai berikut:

1. GuruBK, setelahmengetahuikemampuan 
dan kondisi yang terjadi ada baiknya ini menjadi bahan instrospeksi untuk selalu mengembangkan kompetensinya, terutama kompetensi kepribadian. Sebaiknya guru BK rajin mengikuti seminar, workshop, diklat, dan pelatihan. Guru BK hendaknya rajin mengupgrade ilmu bimbingan dan konseling untuk mengetahui perkembangannya.

2. Kepala sekolah, diharapkan memfasilitasi dan mendorong guru BK untuk mengikuti kegiatan yang dapat meningkatkan kompetensinya. Kepala sekolah juga diharapkan bersedia mengikuti pelatihan terkait manajemen manajemen BK di sekolah dan lebih serius dalam merekrut atau memilih tenaga BK di sekolah.

3. Kepala Dinas Pendidikan Kecamatan Citeureup, diharapkan dapat memberikan perhatian lebih kepada guru BK di SMP yang sebagian besar berlatar belakang pendidikan S1 Non BK dan dapat membuat kebijakan terkait dengan penyediaan guru BK di sekolah.

4. MGBK atau Organisasi Profesi BK, diharapkan dapat mengadakan berbagai seminar, workshop ataupun pelatihan yang dapat meningkatkan kompetensi guru BK.

5. Peneliti selanjutnya, dapat melakukan penelitian sejenis dengan menggunakan pengumpulan data yang bervariasi, tidak hanya angket. Bisa juga meneliti variabel lanjut dari penelitian ini seperti faktor apa saja yang mempengaruhi kompetensi keperibadian guru BK di sekolah atau bagaimana cara pengembangan kompetensi kepribadian guru BK untuk menghasilkan layanan BK yang lebih bermutu.

\section{DAFTAR PUSTAKA}

Hasanudin. (2011). Anxieties/Desires: 90 Insight for Marketing to Youth, Women, Netizen. Jakarta: Gramedia Pustaka Utama.

Peraturan Menteri Pendidikan Nasional Nomor 27 tahun 2008 tentang Standar
Kualifikasi Akademik dan Kompetensi Konselor.

Roqib, M., \& Nurfuadi. (2009). Kepribadian Guru, Upaya Mengembangkan Kepribadian Guru yang Sehat di Masa Depan. Yogyakarta: Grafindo Litera Media.

Sagala, S. (2011). Kemampuan Profesional Guru dan Tenaga Kependidikan. Bandung: Alfabeta.

Saudagar, F., \& Idrus, A. (2011). Pengembangan Profesionalitas Guru. Jakarta: Gaung Persada Press.

Sukardi, D.K. (2008). Proses Bimbingan dan Konseling Di Sekolah. Jakarta: Rineka Cipta.

Sugiyono. (2011). Metode Penelitian Pendidikan Pendekatan Kuantitatif, Kualitatif dan $R \& D$. Bandung: Alfabeta. Wibowo. (2007). Manajemen Kinerja, Jakarta: Raja Grafindo Persada. 
